\title{
PREHRANSKA VARNOST SVETA IN SLOVENIJE
}

\author{
dr. Dušan Plut \\ Oddelek za geografijo, Filozofska fakulteta Univerze v Ljubljani \\ Aškerčeva 2, SI-1000 Ljubljana \\ e-mail: dusan_plut@t-2.net
}

Izvirni znanstveni članek

COBISS 1.01

\section{Izvleček}

V začetku 21. st. se pridelava hrane na prebivalca ni povečevala, hrana pa je postala pomembna strateška dobrina. $\mathrm{V}$ pričakovanih negotovih razmerah nestabilne oskrbe s hrano na globalni ravni postaja vprašanje lokalne, regionalne in državne samooskrbe s hrano zelo pomembno. Slovenija z domačo pridelavo ne pokriva svojih potreb po kmetijsko-živilskih proizvodih. Vendar strokovne ocene kažejo, da Slovenija razpolaga z dovolj velikimi potenciali kmetijskih zemljišč, da prehransko varnost bistveno poveča do leta 2030.

Ključne besede: prehranska varnost, prehranska samooskrba, kmetijstvo, žitne površine, Slovenija

\section{FOOD SECURITY IN THE WORLD AND IN SLOVENIA}

\begin{abstract}
At the beginning of the 21st century food production per capita has not increased and food has become important strategic good. In future uncertain conditions of unstable food supply at global level, the issue of local, regional and state self-sufficient food supply has been ever more important. Slovenia's local production does not cover the country's needs for the agricultural food products. Nevertheless, expert assessments show that Slovenia has sufficiently big potentials in farming lands to essentially improve its food security by the year 2030 .
\end{abstract}

Key words: food security, food self-sufficiency, agriculture, cereal areas, Slovenia 


\section{I.UVOD}

V klasični agrarni geografiji se razvoj (evolucija) kmetijstva v grobem deli v tri faze: krčenje, izkoriščanje in kultivacija prostora (Andreae, 1983, str. 31). Razvoj komercialnega kmetijstva je bil stoletja skoraj v celoti podrejen zgolj ukrepom povečanja produktivnosti in konkurenčnosti kmetijske pridelave ne glede na dolgoročne negativne okoljske in druge posledice. $\mathrm{V}$ zadnjih dveh desetletjih pa se je svetovno kmetijstvo, pomen in odnos do podeželja in pridelave hrane bistveno spremenil (Woods, 2005). Tako postindustrijska družba poleg dela postavlja v ospredje nove vrednote, kot so stik z naravo, varna (ekološko pridelana) hrana, občudovanje in doživljanje tradicionalne kulture (Klemenčič, 2010). $\mathrm{V}$ pričakovanih negotovih razmerah nestabilne oskrbe s hrano na globalni ravni, prevladujočih negativnih učinkih podnebnih sprememb in zaradi spoznanj o negativnih okoljskih učinkih prevoza hrane na velike razdalje postaja vprašanje lokalne in regionalne samooskrbe s hrano ponovno pomembno. Prehranska varnost in lastna pridelava hrane na državni ravni ponovno postajata strateško pomembni vprašanji (Perpar, Udovč, 2010). Slovenija $\mathrm{z}$ domačo pridelavo hrane $\mathrm{v}$ zaostrenih globalnih razmerah ne pokriva svojih potreb po kmetijsko-živilskih proizvodih, stopnja samooskrbe pa se zmanjšuje.

V začetku 21. st. je zagotavljanje prehranske varnosti vse večjega števila prebivalstva na globalni ravni dodatno oteženo zaradi negativnih vplivov podnebnih sprememb. Dvig materialnega blagostanja določenih socialnih skupin v državah v razvoju ter s tem povezane spremembe prehranskih navad (npr. večja poraba mesa) prav tako povečuje svetovno porabo žit. Hrana postaja torej geopolitično pomembna, strateška dobrina. V primeru pomanjkanja hrane na globalni ravni lahko pričakujemo krizne razmere, ki lahko ogrozijo svetovni mir.

Med vzroki pomanjkanja hrane na svetovnem trgu se navajajo novi kupci kmetijskih pridelkov iz držav v razvoju (zlasti Kitajska), praviloma negativne posledice podnebnih sprememb (pogostejše suše in poplave), rast cen mineralnih gnojil, uporaba večjih kmetijskih površin za proizvodnjo biogoriv (etanol, biodizel), obsežne pozidave in erozija kmetijskih zemljišč ter naraščanje porabe žit za prirejo in potrošnjo mesa, zlasti v državah v razvoju. Letna izguba rodovitne prsti zaradi erozije je na Kitajskem 5 milijard ton (Diamond, 2006). Velika poraba energije in proizvedene prometne emisije toplogrednih plinov ob prevozu hrane na velike razdalje so ključni širši negativni okoljski učinki. Obrok iz uvožene hrane (meso, žitni proizvodi, sadje in zelenjava) povzroči štirikrat večje emisije toplogrednih plinov kot enak obrok, kadar se uporabljajo lokalni kmetijski pridelki (Nierenberg, Halweil, 2005).

V obdobju po letu 2007 so se razmere na globalnem trgu s hrano še dodatno zaostrile, prišlo je do destabilizacije planetarne prehranske varnosti. Tako so svetovne cene pšenice, koruze, sladkorja in olja v obdobju 2008-2011 dosegle rekordno visoke vrednosti in negativno vplivale zlasti na blagostanje revnih prebivalcev sveta, ki velik del pičlih dohodkov potrošijo za prehrano. Posledice pogostejših poletnih suš in poplav v številnih državah so nevarno ogrozile prehransko varnost planeta in zarisale vse bolj zaskrbljujočo in geopolitično tvegano podnebno-prehransko podobo toplega planeta. 


\section{KONCEPT PREHRANSKE VARNOSTI INTRAJNOSTNI RAZVOJ}

Prehranska varnost obstaja v primeru, ko imajo vsi prebivalci vedno fizični in ekonomski pristop do zadovoljivih količin zdrave hrane, ki omogoča zadovoljevanje prehranskih potreb za zdravo in aktivno življenje. Raman (2006, str. 356) ugotavlja, da se je pojem prehranske varnosti v zadnjih desetih letih spremenil. Nov pristop k prehranski varnosti se je preumeril zlasti na možnosti trajnostnega povečanja pridelave hrane za lokalne potrebe v obsežnih območjih manj rodovitnih kmetijskih zemljišč v državah v razvoju. Tudi Sage (2012, str. 298) podčrtuje trajnostno zasnovo definicije prehranske varnosti, ki omogoča varno in kulturološko sprejemljivo oskrbo s hrano s pomočjo trajnostnega sistema hrane, ki povečuje samooskrbo skupnosti, socialno pravičnost in demokratičnost odločanja. Trajnostni sistem hrane omogoča pridelavo dovolj zdrave hrane za zadovoljevanje sedanjih potreb in zagotavlja integriteto agro-ekosistemov in naravnega okolja za zadovoljevanje potreb prihodnjih generacij ter spodbuja večjo lokalno pridelavo hrane.

Prehranska varnost je po mnenju Ramana (2006, str. 414) osnova preživetja človeštva in trajnostnega razvoja. Kmetijska trajnostnost je večplastni kmetijsko-podeželski koncept, ki povezuje produktivnost, ohranjanje ekološke vitalnosti, socialnoekonomske enakosti in pravičnosti. Zaradi dviga cen hrane in drugih razlogov se krepi tudi trajnostno urbano kmetijstvo. Prehod h kmetijski trajnostnosti bo zelo zahteven, saj bo potrebno na eni strani zagotoviti oskrbo vse večjega števila svetovnega prebivalstva in hkrati ohranjati rodovitnost prsti ter drugih kmetijskih virov. Koncept in pomen agrarne trajnostnosti se sicer ni pojavil v 20. st., a postaja zaradi izčrpavanja kmetijskih zemljišč in preseganja ekoloških omejitev biološke produktivnosti vse bolj aktualen (Raman, 2006). Tradicionalno kmetijstvo, ekološko, organsko in biodinamično kmetijstvo so nazorni primeri trajnostnega kmetijstva v obdobjih nižje prebivalstvene gostote, v obdobju visoke gostote prebivalstva in globalne grožnje pomanjkanja hrane pa so izzivi kmetijske trajnosti in zagotavljanja prehranske varnosti še bolj zahtevni. Ključni trajnostni izziv kmetijstva je zagotovitev prehranske varnosti človeštva brez ogrožanja delovanja planetarnega ekosistema. Po mnenju Piercea (1990) je potrebno upoštevati naravne zmogljivosti za pridelavo hrane. Čeprav je kmetijstvo zasnovano na prsti kot obnovljivem viru, velja podčrtati, da številni degradacijski procesi (tudi v kmetijstvu) v bogatih in revnih državah zmanjšujejo naravno rodovitnost prsti.

Koncept prehranske varnosti vključuje sposobnost zagotavljanja hrane tudi v izrednih in kriznih razmerah, varno stopnjo potencialne samooskrbe in sledljivost neškodljivo pridelane hrane (Perpar, Udovč, 2010). Strategije zagotavljanja prehranske varnosti posameznega območja ali države običajno vključujejo zagotavljanje trajnostne samooskrbe preko prehranske verige (vključno s pospeševanjem porabe lokalne hrane) in tudi upoštevanje področij, na katera ima lokalna samooskrba neposreden ali posreden vpliv (zdravje, okolje, gospodarstvo, družba, kultura in varnost). Tudi obseg lokalne oskrbe s hrano je zelo odvisen od vodnih virov. Prehranska varnost je namreč tesno odvisna od zagotavljanja zadovoljivih količin vode za namakanje, voda postaja ključna strateška dobrina 21. st. (Pierce, 1990; Mays, 2007). 
Koncept prehranske varnosti poudarja pomen udejanjanja načela trajnostne lokalne oskrbe s hrano. To terja tudi od nas kot posameznikov in kot dela družbe, da razmišljamo o svojem načinu življenja, o posledicah svojih dejanj z vidika razvoja, družbenega napredka in stanja okolja in da na tej osnovi oblikujemo ustrezne rešitve (Resnik Planinc, Ilc, 2010). Regionalne raziskave v Sloveniji pa hkrati podčrtujejo, da zlasti demografske in gospodarske spremembe ključno vplivajo na zmanjševanje kmetijskih zemljišč in možnosti za lokalno (regionalno) oskrbo s hrano (Korošec, Pak, 2010).

\section{GLOBALNE PREHRANSKE RAZMERE}

Posledice prehranske krize kažejo poleg ekonomskih že pretresljive socialne, zlasti v arabskih državah tudi politične posledice. Pogostejše vremenske ujme, skokovite podražitve hrane, odkrite neetične profitne manipulacije monopolistov gensko pridelane hrane so dejansko zgolj površinski znaki globalne prehranske krize. Ali še pridelamo dovolj hrane za svetovno prebivalstvo, ki šteje nad 7 milijard prebivalcev, to število pa se letno poveča še za več kot 70 milijonov? Na začetku 21. st. je bila letna pridelava hrane na prebivalca za $25 \%$ večja kot v zgodnjih 60. letih 20. st. in je v obdobju 2008-2010 znašala 2,2 milijard ton žit na leto. V 80. letih 20. st. je prišlo do stabilizacije letne pridelave hrane na prebivalca, ki je leta 2010 znašala okoli $310 \mathrm{~kg}$ žit na prebivalca. V nekaj zadnjih desetletjih je bila rast pridelave hrane sicer večja od rasti svetovnega prebivalstva, vendar se je kljub temu število lačnih povečalo (Stutz, Warf, 2005). Upoštevati je namreč potrebno dejstvo, da je hrana regionalno zelo neenakomerno razporejena. Tako je bila leta 2009 lačna več kot ena milijarda prebivalcev, kar je največ po letu 1970, obenem pa se v bogatih državah večji del žit uporabi kot hrana za živali, veliko hrane pa je končalo v smetnjakih. Tako je svet vse bolj oddaljen od cilja, da bi bilo leta 2015 na svetu lačnih največ 420 milijonov prebivalcev.

$\mathrm{Na}$ začetku 21. st. obsegajo obdelana zemljišča (njive, vrtovi, intenzivni travniki, vinogradi, sadovnjaki) $11 \%$ kopnih površin, pašniki $25 \%$ in gozdovi $30 \%$, ostalo so zaledenele površine, tundra, puščava in urbana območja. Raba prostora za kmetijstvo oziroma agroekosistemi so prostorsko najbolj razširjena pokrajinska raba na planetu, ključni vzrok za širjenje pa je povečanje potreb po pridelavi hrane za rastoče svetovno prebivalstvo. Polovica celotnega kopnega (vključno s puščavami, skalami in ledenimi površinami) je pod vplivom človeške vrste. Skoraj tri četrtine bioproduktivnih površin planeta so delno ali v celoti pod vplivom človeštva, zgolj četrtina ozemlja je t.i. divjina (Lincoln, 2006). Evropa je celina, kjer na 85 \% površja dominira človeška vrsta. Okoli četrtino planetarne potencialne neto primarne produkcije neposredno (kmetijski donosi) ali posredno (spremembe produktivnosti zemljišč zaradi človekove rabe) uporablja človeška vrsta; najmočnejši večplastni pritiski na naravne ekosisteme so v Jugovzhodni Aziji, Evropi in nekaterih regijah Severne Amerike.

Obdelovalne površine obsegajo po podatkih FAO okoli 13 milijonov km², med celinami pa so velike razlike. V Afriki, celini z najvišjo letno stopnjo rasti prebivalstva, obdelovalne površine obsegajo le dobrih $6 \%$ vseh njenih površin, oziroma skoraj polovico pod svetovnim povprečjem. In prav na območju prehransko najbolj ranljive Afrike tuji vlagatelji in države jemljejo v zakup obsežna kmetijska zemljišča, kar še dodatno ogroža že tako pičlo oskrbo 
lokalnega prebivalstva s hrano. Od 27 držav sveta, ki že imajo probleme z nacionalno prehransko varnostjo, jih je 22 v Afriki (Stutz, Warf, 2005). Razlog več, da bi bilo potrebno tudi etično sporen proces kmetijskih zakupov kot sodobne oblike zasužnjevanja afriških in drugih agrarnih ekosistemov ter kmetov prepovedati na globalni ravni. Tudi evropske države kupujejo ali najemajo zemljišča v Afriki, Aziji in Braziliji ter pridelujejo energetske rastline. Na ta način še dodatno povzročajo težave z zagotavljanjem hrane in lokalne oskrbe prebivalcem revnih držav (Perpar, Udovč, 2010).

Med državami z največjimi obdelovalnimi površinami na prebivalca so velike izvoznice hrane: Avstralija, Kanada, Nova Zelandija, ZDA, Argentina, Kazahstan in Rusija. V gospodarsko razvitih makroregijah sveta pripada posameznemu prebivalcu skoraj dvakrat več obdelovalnih površin kot prebivalcu držav v razvoju. Zaradi naraščanja prebivalstva se $\mathrm{v}$ državah $\mathrm{v}$ razvoju obdelovalne površine na prebivalca hitreje zmanjšujejo kot v razvitih državah, $v$ številnih državah sveta je prisotna izrazita pozidava tudi najboljših kmetijskih zemljišč. Pozidava zaradi širjenja urbanizacije, suburbanizacije in gradnje prometnic ne zmanjšuje zgolj možnosti pridelave hrane, temveč zmanjšuje tudi opravljanje nezamenljivih ekosistemskih storitev na bioproduktivnih zemljiščih, vključno s ponori ogljika.

V letu 1981 je bilo na svetu med obdelovalnimi površinami največ žitnih površin (zlasti pšenica, koruza, riž), in sicer 730 milijonov ha, v letu 2006 so se žitne površine zmanjšale na 695 milijonov ha. V obdobju 1950-2007 so se žitne površine na prebivalca predvsem zaradi rasti svetovnega prebivalstva več kot prepolovile, saj so se zmanjšale z 0,23 ha na zgolj 0,10 ha. Do leta 2050 naj bi se površine za pridelavo žit na prebivalca znižale pod 0,08 ha na prebivalca, torej pod globalno (ne le regionalno) kritično mejo prehranske varnosti.

Ključni problemi globalnega kmetijstva so zelo neenakomerna porazdelitev sicer glo-

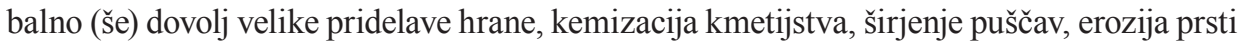
(na več kot 900 milijonih ha kmetijskih zemljišč), velika poraba vode, pozidave kmetijskih zemljišč in naraščanje svetovnega prebivalstva. Razvoj hibridnih sort žit, trikratno povečanje namakanih kmetijskih površin, večkratne žetve na leto in devetkratno povečanje porabe mineralnih gnojil po letu 1950 so ključno vplivali na potrojitev svetovne pridelave žit, a hkrati so se povečali kmetijski okoljski pritiski. Povečanje porabe mineralnih gnojil in zaščitnih sredstev pa ni več obet za nadaljnje povečanje pridelave hrane na območjih, kjer je njihova poraba na hektar že optimalna in hkrati okoljsko obremenjujoča. V obdobju po letu 1980 se letna pridelava žit na prebivalca planeta ni več pomembno povečevala in se je dejansko ustalila na okoli 300-350 kg. T.i. komercialno (konvencionalno) kmetijstvo označujejo obsežna mehanizacija, intenzivna raba fosilnih goriv, monokulture, uvajanje gensko spremenjenih organizmov, raba sintetičnih kemičnih gnojil in pesticidov ter $18 \%$-ni neposredni prispevek h globalnim emisijam toplogrednih plinov. Sodobni agrarni sistemi pridelave hrane največ prispevajo k porabi vode, podnebnim spremembam, zmanjševanju biotske raznovrstnosti in k siromašenju prsti (Sage, 2012). Letne izgube prsti zaradi erozije so ocenjene na 75 milijard ton, 10 kalorij žit pa je potrebnih za proizvodnjo 1 kalorije govejega mesa.

Kmetijstvo je največji svetovni porabnik vode, saj potroši $70-80 \%$ vse vode. Pridelava enega kilograma pšenice namreč zahteva 900 litrov vode, koruze 1400 litrov, en kg govedine pa 15.000-20.000 litrov (Nierenberg, Halweil, 2005, str. 77; Raman, 2006, str. 428). 
V številnih državah sveta je voda vse bolj omejitveni dejavnik kmetijstva. S pomembnim toplogrednim prispevkom (okoli tretjine, če se upošteva še krčenje gozda zaradi kmetijstva) tudi samo kmetijstvo pospešuje podnebne spremembe, ki s povratnimi loki ogrožajo samega povzročitelja. Če bi vsi prebivalci sveta pridelovali hrano na podoben način in potrošili toliko hrane (s povprečno letno porabo mesa $120 \mathrm{~kg}$ na prebivalca in s tem povezano veliko porabo žit za prehrano domačih živali) kot povprečen prebivalec ZDA, bi bile znane svetovne rezerve nafte potrošene v 15 letih. Mehanizirano in kemizirano kmetijstvo je praviloma (vendar ne vedno) bolj produktivno od tradicionalnega kmetijstva $\mathrm{v}$ državah $\mathrm{v}$ razvoju. Vendar je tradicionalno kmetijstvo praviloma bistveno bolj energetsko učinkovito in trajno, saj ohranja naravno rodovitnost prsti, kar je ključnega pomena za prihodnje generacije.

Komercialno kmetijstvo je izrazito kapitalsko in energetsko intenzivno, sicer produktivno, a zaposluje malo ljudi (manj kot $5 \%$ v gospodarsko razvitih državah) in močno obremenjuje okolje (Stutz, Warf, 2005). Tako zasnovano kmetijstvo je netrajnostno, saj uničuje naravne vire, od katerih je eksistenčno odvisno. Rodovitnost prsti upada zaradi erozije in zastrupljanja prsti, teptanja prsti in destrukcije organskih snovi. Vodna oskrba je ogrožena zaradi izčrpavanja vodnih virov in kmetijskega onesnaževanja. V mehaniziranem kmetijstvu se uporabljajo neobnovljiva fosilna goriva, zapostavlja pa se trajna ekonomija lokalnih skupnosti, saj se kmetijski produkti praviloma prodajajo na oddaljenih trgih. Dolgi prevozi hrane prinašajo tudi izgubljanje prehranske vrednosti živil, ki so hkrati tudi z vidika zdravja manj kakovostna in pogosto še dodatno kemijsko obdelana, da vzdržijo dolge prevoze (Perpar, Udovč, 2010).

\section{PREHRANSKA (NE)VARNOST PLANETAV PRVI POLOVICI 2I.STOLETJA}

Trajnostno zasnovano zarisovanje prihodnosti poudarja potrebno zadovoljevanje (zgolj) ključnih materialnih potreb vsem prebivalcem in opozarja na nujnost čimprejšnje stabilizacije svetovnega prebivalstva. Primerno kakovost življenja naj bi dosegli s pomočjo razvoja alternativ sedanji visoko energetski, materialno intenzivni pridelavi in potrošnji. Trajnostno gospodarstvo naj bi označevalo (Stutz, Warf, 2005, str.114):

- preusmeritev v organsko kmetijstvo, zasnovano na sončni energiji;

- rabo obnovljivih virov energije;

- rabo primernih tehnologij in delovno intenzivnih metod pridelave;

- rabo lokalnih virov, decentralizacijo produkcije zaradi potrebe po večji samooskrbi in zmanjšanju stroškov in posledic prevoza.

Voda in hrana sta ključni dobrini preživetja vsakega od nas, vodna, prehranska, energetska in okoljska varnost so ključne sestavine širše pojmovane nacionalne varnosti 21. st. Po mnenju številnih strokovnjakov je zagotovitev trajne oskrbe z zdravo hrano (pričakovano povečanje potreb po hrani za okoli $100 \%$ do leta 2050) za vse prebivalce zaradi podnebnih sprememb, realne možnosti številnih regionalnih konfliktov in večje socialne nestabilnosti 
največji in verjetno najbolj zahteven globalni izziv 21. st. Povečanje svetovnega prebivalstva za okoli 2 milijardi do leta 2050 in spremembe v sestavi hrane (od žit k mesu) ob dvigu materialnega blagostanja bo zelo povečalo povpraševanje po kmetijskih pridelkih (The European environment, 2011). Po podatkih FAO bo potrebno sedanjo pridelavo hrane do leta 2050 povečati za $70 \%$. Letna pridelava bi se morala povečati z 2,1 milijarde ton na 3 milijarde ton, letna prireja mesa pa naj bi se povečala z 200 milijonov ton na 470 milijonov ton (Odnos do kmetijske zemlje, 2010). Glede na nujnost odprave lakote in predvideno povečanje potreb po hrani v številnih državah v razvoju do srede 21. st. so v prihodnjih nekaj desetletjih planetarno dejansko na razpolago naslednje možnosti:

- povečanje kmetijskih površin;

- povečanje donosov na obstoječih kmetijskih površinah in raba novih virov hrane;

- bistveno zmanjšanje t.i. odvržene hrane v bogatih državah (v smeteh konča tudi do tretjina pripravljene hrane) in pravičnejša porazdelitev hrane po svetu;

- $\quad$ spremembe prehrambenih navad z ohranjanjem deleža mesa iz živinskih farm (uporaba žit) v prehrani prebivalcev držav v razvoju in vztrajnim zmanjševanjem porabe mesa $\mathrm{v}$ državah materialnega blagostanja.

Po eni od ocen kmetijskih strokovnjakov bi teoretično sicer lahko podvojili obdelovalne površine, zlasti na račun novih zemljišč v Afriki, Južni Ameriki in Avstraliji. Vendar opozarjajo, da so realne možnosti širjenja kmetijskih površin zaradi okoljskih razlogov, zaradi nujnosti ohranjanja možnosti za opravljanje ekosistemskih storitev (ohranjanje tropskih gozdov) zgolj regionalno možne, na globalni ravni pa zlasti zaradi tvegane erozije prsti dejansko zelo omejene. Do leta 2030 naj bi se kmetijske površine po zelo optimističnem scenariju povečale za največ $10 \%$, kasneje pa se kmetijske površine zaradi ogrožanja eksistenčno pomembnih okoljskih storitev naravnih ekosistemov naj ne bi širile (The European environment, 2011). Poudariti velja, da je že sedanje širjenje kmetijskih zemljišč povzročilo prekomerno sekanje tropskih gozdov, povečalo puščave in površine zaslanjenih prsti. Določene možnosti dodatne pridelave hrane so na mestnih zemljiščih (zasebni vrtovi, tudi strehe stavb).

Več možnosti je za povečanje donosov na obstoječih kmetijskih površinah v številnih državah v razvoju, kjer so npr. donosi žit tudi za nekajkrat manjši od donosov v razvitih državah. Večji donosi pa so bili v preteklosti praviloma doseženi na račun izčrpavanja naravne rodovitnosti prsti, z večjo porabo mineralnih gnojil in zaščitnih sredstev, s pomočjo razsipnih oblik namakanja. Trajnostno zasnovano namakanje, sodobne in inovativne sonaravne tehnike integriranega in ekološkega kmetovanja, kolobarjenje, večkratne žetve na leto in druge možnosti pa omogočajo trajnejše dvige kmetijskih donosov, ki so primerljivi z donosi konvencionalnega kmetijstva. V območjih, kjer je dovolj vode in so primerne temperature, so donosi ob namakanju za 2-3-krat večji kot brez namakanja (Sage, 2012, str. 79). Poudariti velja, da v ceni hrane konvencionalnega kmetijstva niso vključeni zunanji okoljski in podnebni stroški, ki so tako veliki, da bi popolnoma spremenili tudi cenovna razmerja med konvencionalno in biološko pridelano hrano. Po vsej verjetnosti bodo cene hrane tudi zaradi navedenih razlogov v prihodnje še naraščale. 
Poraba in delež mesa bi se morala zlasti zaradi energetsko-okoljskih razlogov v državah blagostanja zmanjšati, v planetarno in geopolitično zaostrenih prehranskih razmerah pa bi se morala poraba žit za prirejo mesa zelo omejiti. Sredi 21. st. bo na svetu verjetno živelo 9-10 milijard ljudi. Površina potrebnih kmetijskih zemljišč bo odvisna od potrebne količine in sestave hrane ter intenzivnosti kmetijske obdelave. Prevlada vegetarijanskega načina prehranjevanja svetovnega prebivalstva bi zahtevala največ $700-800 \mathrm{~m}^{2}$ intenzivno obdelanih kmetijskih zemljišč na prebivalca, prevlada velikega deleža mesa in mlečnih izdelkov pa vse do $4000 \mathrm{~m}^{2}$ (Sage, 2012, str. 74). Za zadovoljevanje povprečne dnevne porabe $2500 \mathrm{kcal}$ na prebivalca s $30 \%$ živalskih proizvodov bi bilo potrebno okoli $1500 \mathrm{~m}^{2}$ povprečno intenzivno obdelanih kmetijskih zemljišč, zelo visok delež mesa v prehrani pa bi zahteval okoli $3000 \mathrm{~m}^{2}$. Za prehrano 10 milijard prebivalcev bi sredi 21. st. torej potrebovali 880-3000 milijonov ha zemljišč, najbolj verjetno pa 1100-1300 milijonov ha. To pomeni, da v primeru manjšega deleža mesa in mlečnih izdelkov v prehrani svetovnega prebivalstva dejansko ne bi potrebovali dodatnih kmetijskih zemljišč (Sage, 2012).

Gensko spremenjene sorte monopolnih multinacionalk (Monsanto) so po mnenju vse bolj številnih okoljevarstvenikov dolgoročno zdravstveno in ekosistemsko (zamenjava prilagojenih avtohtonih sort s tujimi sortami) tvegane in zato zagovarjajo načelo previdnosti, torej so proti njihovi uporabi. Zato celotna kmetijska paradigma potrebuje temeljito prenovo v smeri ekosistemsko varnih, trajnostnih sistemov pridelave hrane, prilagajanja na podnebne spremembe in zmanjšanja velikih kmetijskih emisij toplogrednih plinov ter spremembe prehranskih navad. Na globalni in regionalnih ravneh je potrebna zaščita prsti in stroga zaščita nenadomestljivih rodovitnih kmetijskih zemljišč kot ključen trajnostni kmetijski cilj. Pričakovana večja delovna intenzivnost sonaravnih oblik kmetijstva pa razen možnosti zaposlitve povečuje konkurenčnost manjših kmetij, ki jih je konvencionalno kmetijstvo skoraj uničilo.

Zaradi vse bolj prisotne globalne prehranske in okoljske negotovosti ter dvomov v dolgoročno okoljsko trajnost sedanjega načina reševanja problema lakote, pridelave in razporeditve hrane je vse več strokovnjakov, ki poudarjajo vse večji pomen prehranske samooskrbe držav, regij, lokalnih skupnosti in kmetijskih praks, ki so prilagojene lokalnim okoljskim zmogljivostim. Bogate države bi morale tudi zaradi lastnih varnostnih in dolgoročnih razvojnih interesov finančno pomagati državam v razvoju, da bi lahko same prehranile prebivalce. Prevozi hrane na velike razdalje so tudi zaradi dodatne porabe energije in okoljskih pritiskov netrajnostni.

Po mnenju Browna $(2005 ; 2008)$ je nujna tudi čimprejšnja stabilizacija svetovnega prebivalstva kot eden ključnih dejavnikov za zagotavljanje tudi sicer negotove globalne prehranske varnosti srede 21. st. Morali bi vložiti dodatni trud, da svetovno prebivalstvo leta 2050 ne bo preseglo 8 milijard. Vse bolj namreč dozoreva spoznanje tudi na globalni politični ravni, da planet s hrano in drugimi materialnimi dobrinami na sedanji ravni držav blagostanja ne bo mogel dolgoročno oskrbovati povprečne svetovne družine, ki bo imela več kot dva otroka. Pa tudi ne družine z enim otrokom, ki bo vsak dan imela najmanj en obilen mesni obrok.

V primeru, da znaša letna poraba žit na prebivalca le $200 \mathrm{~kg}$ (poraba v Indiji), bi lahko z 2 milijardama ton žit prehranili 10 milijard prebivalcev, v primeru porabe na ravni Italije 
(400 kg) 5 milijard in v primeru porabe žit na ravni ZDA (800 kg in več) zgolj 2,5 milijarde prebivalcev. Za prehrano, zasnovano na mesu, se potroši v povprečju štirikrat več virov kot za vegetarijansko prehrano. V obdobju 1978-2001 pa se je na Kitajskem poraba mesa povečala za štirikrat (Diamond, 2006). Nekateri strokovnjaki zaradi pomanjkanja hrane in okoljskih razlogov torej poudarjajo potrebo po premiku k bolj vegetarijanski prehrani v gospodarsko razvitih državah (Maxey, 2007). Vendar je potrebno dodati, da je živinoreja, ki ne uporablja žit kot krme, okoljsko in prehransko praviloma dokaj sprejemljiva, saj npr. v gorskem svetu večine pašnikov in travnikov ni možno uporabljati za pridelavo žit oziroma za njivske površine.

Brown $(2005 ; 2008)$ predlaga naslednje ključne usmeritve za svetovno kmetijstvo, ki bi bile tudi okoljsko primerne:

- povečanje kmetijskih zemljišč z večkratnimi letnimi žetvami - zlasti v zmernih geografskih širinah (ZDA, Evropa, severna Kitajska, severna Indija, Argentina, vzhodna Afrika itd.);

- povečanje vodne produktivnosti - višja cena vode, zamenjava vodno intenzivnih kmetijskih kultur in s sodobnimi tehnologijami podprto učinkovito namakanje (sedanje visoko svetovno povprečje je okoli 1000 ton porabljene vode za pridelavo 1 tone žit);

- zmanjšanje porabe žit kot krme za živali (mesni proteini) v gospodarsko razvitih državah;

- učinkovitejša pridelava mesnih proteinov - povečanje sicer zelo različne učinkovitosti energetske pretvorbe živali za žita (govedo $1: 7$, prašiči $1: 4$, perutnina $1: 2$, akvakultura $1: 2$ in manj), večja uporaba soje za krmo živali;

- novi produkcijski sistemi za proteine - uporaba ostankov žetev za prirejo mleka, prehrambene verige med kmetijstvom in akvakulturo (npr. Kitajska, Vietnam).

\section{PREHRANSKA VARNOST SLOVENIJE}

Slovenija je ena izmed izbranih držav sveta, ki za varno preživetje in zmerno blagostanje vseh prebivalcev v prvi polovici 21. st. razpolaga s ključnimi strateškimi trajnostnimi okoljskimi kapitali. Ob varčni in stabilni, sonaravni rabi omogočajo trajno in zanesljivo samooskrbo z vodo, obnovljivimi viri energije, lesom ter s tem povezanimi ključnimi ekosistemskimi funkcijami. Med navedenimi nacionalno prednostnimi sonaravnimi samooskrbnimi polji pa bo po našem mnenju ponovno doseganje varne stopnje prehranske samooskrbe, pridelava domače kakovostne in zdrave hrane po vsej verjetnosti najbolj zahtevna strateška trajnostna razvojna naloga na državni ravni. Dovolj velika kmetijska zemljišča in ohranjanje naravne rodovitnosti prsti na kmetijskih zemljiščih okoli 75.000 kmetijskih gospodarstev sta ključna naravna predpogoja za zagotavljanje prehranske varnosti Slovenije v že začetem obdobju stabilizacije njenega prebivalstva.

Slovenija z domačo pridelavo ne pokriva svojih potreb po kmetijsko-živilskih proizvodih. Stopnja samooskrbe v Sloveniji je za živalske proizvode precej višja kot za rastlinske. Stalni presežki se pojavljajo pri hmelju, mleku, perutninskem mesu in svežih jabolkih, bilanca pa je dokaj izravnana pri mesu govedi in drobnice ter jajcih. Največji primanjkljaj je pri sladkorju, rastlinskem olju, velik je tudi pri zelenjavi (60\%), žitih (40\% primanjkljaj pri vseh žitih in $50 \%$ pri pšenici), krompirju (30-40\%) in svinjskem mesu (30\%). Slovenija 
v splošnem ostaja neto uvoznica kmetijsko-živilskih proizvodov, njen kmetijski trgovinski primanjkljaj pa se je po vstopu v EU še povečal (Perpar, Udovč, 2010).

$\mathrm{V}$ geografsko in klimatsko podobnih razmerah bi za varno prehransko oskrbo v Sloveniji potrebovali na prebivalca najmanj $3000 \mathrm{~m}^{2}$ kmetijskih zemljišč v uporabi (njiv, trajnih travnikov in pašnikov, sadovnjakov, vinogradov; Hrustel Majcen, 2004) oziroma 2500$3000 \mathrm{~m}^{2}$ obdelovalnih kmetijskih zemljišč (Odnos do kmetijske zemlje, 2010). Ob upoštevanju dejstva, da so na dveh tretjinah kmetijskih zemljišč v Sloveniji izraziti omejitveni naravni dejavniki pridelave hrane in je manjši delež njivskih površin, je dejansko potrebna površina kmetijskih zemljišč v uporabi za varno oskrbo z doma pridelano hrano še nekoliko večja. Leta 1991 je bilo v Sloveniji 561.294 ha kmetijskih zemljišč v uporabi oziroma $2833 \mathrm{~m}^{2}$ na prebivalca, kar je že bilo nekoliko pod ravnijo zagotavljanja varne prehranske oskrbe (preglednica 1). V letu 2000 je bilo 508.960 ha kmetijskih zemljišč v uporabi oziroma $2571 \mathrm{~m}^{2}$ na prebivalca, leta 2009 pa le še 468.496 ha oziroma $2297 \mathrm{~m}^{2}$ na prebivalca, kar je bistveno pod povprečjem EU-27 (3510 m² na prebivalca) (Key figures on Europe, 2010; preglednica 2). Glede zagotavljanja prehranske varnosti na podlagi lastnih kmetijskih zemljišč je Slovenija povsem na koncu lestvice držav članic EU (Perpar, Udovč, 2010).

Preglednica 1: Slovenija - kmetijska zemljišča (1991-2030)

Table 1: Slovenia-agricultural land (1991-2030)

\begin{tabular}{|c|c|c|c|}
\hline & 1991 & 2009 & $2030-$ predlog \\
\hline Kmetijska zemljišča v uporabi (ha) & 561.000 & 468.000 & $600.000-650.000$ \\
\hline Kmetijska zemljišča v uporabi na prebivalca $\left(\mathrm{m}^{2}\right)$ & 2833 & 2297 & $3000-3300$ \\
\hline Njive in vrtovi (ha) & 246.000 & $\begin{array}{r}175.000 \\
(2010: 170.149)\end{array}$ & $250.000-300.000$ \\
\hline Njive in vrtovi na prebivalca $\left(\mathrm{m}^{2}\right)$ & 1242 & 858 (2010: 830) & $1250-1500$ \\
\hline Površine žitaric - skupaj (ha) & 121.000 & $\begin{array}{r}101.000 \\
(2010: 93.900)\end{array}$ & $140.000-160.000$ \\
\hline Površine žitaric na prebivalca $\left(\mathrm{m}^{2}\right)$ & 611 & 495 (2010: 458) & $700-800$ \\
\hline Površine pod pšenico in koruzo za zrnje $\left(\mathrm{m}^{2}\right)$ & 103.000 & 74.000 & $110.000-130.000$ \\
\hline Pridelek pšenice in koruze za zrnje (t) & $\begin{array}{r}510.000 \\
(1989-1991)\end{array}$ & $\begin{array}{r}450.000 \\
(2007-2009) \\
(150.000 \text { t pšenice })\end{array}$ & $\begin{array}{r}600.000-700.000 \\
(250.000-300.000 \mathrm{t} \\
\text { pšenice })\end{array}$ \\
\hline Gozdne površine na prebivalca $\left(\mathrm{m}^{2}\right)$ & 5409 & 5814 & $5000-5400$ \\
\hline
\end{tabular}

Viri/Sources: Statistični letopis RS, 1992, 2010, 2011

Leta 1960 je bilo v Sloveniji okoli 300.000 ha njiv in vrtov oziroma $1875 \mathrm{~m}^{2}$ na prebivalca in leta 1991246.000 ha oziroma $1242 \mathrm{~m}^{2}$ na prebivalca. Leta 2009 je bilo le še 175.000 ha njiv in vrtov (od tega je bilo 101.000 ha žitnih in 54.000 ha površin za krmne rastline) oziroma pičlih $858 \mathrm{~m}^{2}$ na prebivalca, leta 2010 pa 170.000 ha oziroma le še $830 \mathrm{~m}^{2}$ na prebivalca. Več kot polovica njiv je torej bila namenjena pridelavi žit, zlasti koruze za zrnje in pšenice, skoraj tretjina pa pridelavi zelene krme, med katero prevladujejo silažna koruza ter trave in travno-deteljne mešanice (Poročilo o stanju kmetijstva ..., 2010). Koruzna polja se namenjajo 
tudi pridelavi silaže kot surovinske osnove vse večjemu številu bioplinarn. Tudi evropsko določilo o potrebnem obsegu pridelave biogoriv zmanjšuje pridelavo za prehranske namene (Perpar, Udovč, 2010).

Preglednica 2: Kmetijska zemljišča EU-27 in Slovenije (2007-2009)

Table 2: Agricultural land in EU-27 and in Slovenia (2007-2009)

\begin{tabular}{|c|c|c|}
\hline & EU-27 (2007) & Slovenija (2009) \\
\hline $\begin{array}{l}\text { Delež kmetijskih zemljišč v uporabi od skupne } \\
\text { površine (\%) }\end{array}$ & 40,1 & 24,3 \\
\hline Kmetijska zemljišča v uporabi na prebivalca $\left(\mathrm{m}^{2}\right)$ & 3510 & 2297 \\
\hline Obdelovalne površine $(\%)$ & 24,2 & 8,6 \\
\hline Obdelovalne površine na prebivalca $\left(\mathrm{m}^{2}\right)$ & 2080 & 858 \\
\hline Gozdne površine na prebivalca $\left(\mathrm{m}^{2}\right)$ & $\begin{array}{r}3540 \\
\text { (za } 42 \% \text {-no gozdnatost } \\
\text { EU-27) }\end{array}$ & $\begin{array}{r}5814 \\
\text { (za } 58 \% \text {-no gozdnatost } \\
\text { Slovenije) }\end{array}$ \\
\hline
\end{tabular}

Viri/Sources: Key figures on Europe, 2010; Statistični letopis RS, 2010; Suhadolc in sod., 2010

Slovenija je po obsegu kmetijskih obdelovalnih površin (njive in vrtovi) na repu držav članic EU, saj je med 27 državami uvrščena na 24. oziroma 25. mesto. Leta 2009 je bilo namreč samo še 8,6 \% obdelovalnih površin (1900: 19 \%; 1953: 18 \% in 1991: 11 \%) in 24,3 \% kmetijskih površin v uporabi glede na celotno površino države (preglednica 2). Evropsko povprečje je bilo leta 2007 24,2 \% obdelovalnih oziroma 40,1 \% skupnih kmetijskih površin v uporabi (Key figures on Europe, 2010; Suhadolc in sod., 2010). V obdobju 2002-2007 je bilo v Sloveniji pozidanih 19.712 ha, od tega $65 \%$ kmetijskih zemljišč oziroma 7 ha kmetijskih površin dnevno (Odnos do kmetijske zemlje, 2010; Perpar, Udovč, 2010).

V obdobju 1991-2009 se je v Sloveniji zmanjšala površina kmetijskih zemljišč v uporabi za 93.000 ha oziroma za 17 \%, njivskih površin pa za 71.000 ha oziroma za 29\%. V letu 2010 so kmetijska gospodarstva upravljala z okoli 500.000 ha kmetijskih zemljišč, uporabljala pa okoli 467.000 ha. V primerjavi s podatki popisa iz leta 2000 so se skupna kmetijska zemljišča v uporabi zmanjšala za okoli 19.000 ha oziroma za slabe 4 \% (Ocena stanja v kmetijstvu ..., 2011).

V letu 2008 je bila splošna stopnja prehranske samooskrbe Slovenije le še okoli 50 \%, okoli leta 1970 pa skoraj 70 \%. Leta 2007 je bilo svetovno povprečje $1000 \mathrm{~m}^{2}$ žitnih površin na prebivalca, v Sloveniji pa je bilo istega leta okoli 100.000 ha žitnih površin oziroma le $500 \mathrm{~m}^{2}$ na prebivalca. V letu 2010 je bilo s $7 \%$ manj površin požetih 152.000 ton pšeničnega zrnja (75 kg/prebivalca), kar je za $8 \%$ več od zadnjega petletnega povprečja (2005-2009: 140.000 ton). Doseženi hektarski pridelek pšenice je bil med boljšimi v zadnjih petih letih in je znašal 4,8 t/ha (Ocena stanja v kmetijstvu ..., 2011). Pridelava koruze je leta 2010 znašala 300.000 ton, oziroma je bila v okviru povprečja za zadnja leta.

V letu 1991 je bila ocenjena agregatna stopnja samooskrbe s hrano 93,3 \%, očiščena stopnja samooskrbe zaradi uvoza močnih krmil pa 78 \%. Sodobni izračuni Kmetijskega inštituta Slovenije pa kažejo 33-70 \%-no stopnjo samooskrbe rastlinskih proizvodov (Odnos do kmetijske zemlje, 2010). Najbolj očiten razlog strateško nevarno nizke stopnje prehranske 
samooskrbe Slovenije je zmanjšanje njivskih površin (in s tem posredno žitnih površin), pomembna pa je tudi nizka stopnja rabe celotnega naravnega kmetijskega potenciala.

Pričakovane podnebne spremembe, zlasti večja sušnost slovenskih pokrajin, negativno vplivajo na vodne in prehranske razmere (Suhadolc in sod., 2010). Vendar strokovne ocene kažejo, da Slovenija razpolaga z dovolj velikimi potenciali kmetijskih zemljišč in vodnih virov, da lahko sedanjo varnostno tvegano, zelo nizko stopnjo splošne prehranske samooskrbe poveča na varno stopnjo. Glede na obseg in sestavo pokrajinskih ekosistemov, ohranjanje pokrajinske in biotske raznovrstnosti, ohranjanje sposobnosti opravljanja ekosistemskih funkcij, ohranjanje poselitvenega vzorca vzpetega sveta in preživetveno nujnost povečanja pridelave hrane predlagamo, da bi bilo leta 2030 v Sloveniji največ $50 \%$ gozdnih, nad 40 \% agrarnih ekosistemov in največ $10 \%$ (8 \%) nerodovitnih površin. Leta 1875 je bilo zgolj 37 \% gozdnih površin, leta $195343 \%$, leta $198150 \%$ in leta 2009 po podatkih Zavoda za gozdove RS 59 \%. Približno polovična gozdnatost ozemlja Slovenije na račun delne prenove zaraščenih površin v (nekdanja) kmetijska zemljišča bi bila ekosistemsko, prehransko, lesno in poselitveno dovolj uravnotežena.

$\mathrm{Z}$ vidika koncepta okoljskega prostora bi morali zaradi dosežene stabilizacije prebivalstva postopno stabilizirati tudi obseg pozidanih površin. Zelo omejeno in nadzorovano povečanje pozidanih površin na določenem območju bi morala spremljati površinsko enaka kmetijska rekultivacija opuščenih, neuporabnih pozidanih zemljišč, kar je seveda zelo zahtevna naloga. Glede na geografske, zlasti geomorfološke in podnebne razmere bo Slovenija tudi v prihodnje imela večji delež površja pod gozdom. Vendar so po letu 1960 praviloma stihijski demografski procesi izseljevanja prebivalstva iz hribovitega sveta ('erozija prebivalstva') hkrati povzročili prekomerno splošno gozdnatost države, ki med drugim v specifičnih geografskih razmerah Slovenije ne povečuje več sicer izjemne biotske raznovrstnosti. Splošno zmanjševanje kmetijskih zemljišč zaradi opuščanja obdelave in obsežne pozidave na pretežno najbolj rodovitnih ravninskih območjih je tvegano povečalo njeno prehransko odvisnost, v planetarno pričakovanem in geopolitično nevarnem obdobju še večjega pričakovanega globalnega pomanjkanja hrane.

Do leta 2030 (2035) bi morali obseg kmetijskih zemljišč povrniti na stanje okoli leta 1960. Glede na geografske in posestne razmere, velik delež (dve tretjini) kmetijskih območij z omejitvenimi naravnimi razmerami za pridelavo hrane (težji pridelovalni pogoji), velik delež varovanih in vodovarstvenih območij (na več kot polovici državnega ozemlja), prednostno vodooskrbno vlogo prodnih ravnic (obvezna nadomestila kmetom za skromnejše kmetijske donose) in druge razloge bi morali kmetijsko proizvodnjo skoraj v celoti usmeriti v pridelavo integrirane in ekološko pridelane hrane (kljub nekoliko manjšim, a trajnim donosom) za oskrbo prebivalstva, $\mathrm{z}$ bistveno večjim poudarkom na žitih (zlasti na pšenici, ne toliko na koruzi), pa tudi na bistveno večji pridelavi zelenjave (trenutno le $40 \%$-na samooskrba), sadja in delno grozdja. V letih 2008 in 2009 je bil v povprečju uvoz žit v primerjavi z izvozom več kot petkrat večji, celotni uvoz agroživilstva (1,6 milijarde evrov) pa je bil v primerjavi z izvozom (700 milijonov evrov) leta 2009 več kot dvakrat večji (Poročilo o stanju kmetijstva ..., 2010). Pridelava živinske krme bi morala biti zlasti v ravninskem svetu omejena, v vzpetem svetu pa naj bi, poleg sadovnjakov in vinogradov, travniške in pašniške površine omogočale tradicionalno, bolj humano živinorejo (govedoreja, ovčereja itd.). 
Tudi zaradi podnebnih sprememb je potrebno kmetijsko pridelavo prilagoditi naravnim razmeram in sonaravno, ekosistemsko ter večplastno pretehtano povečati kmetijske površine za namakanje. Zelo omejena pridelava kmetijskih rastlin za biogorivo (2010: 5300 ha površin oljne ogrščice in uporaba silažne koruze za proizvodnjo bioplina) bi bila glede na potrebe po hrani možna skoraj izključno le na zastrupljenih oziroma drugače degradiranih površinah. V letu 2010 je bila v celoti ukinjena pomoč za energetske rastline. Z vidika prednostne rabe pičlih kmetijskih zemljišč za pridelavo hrane je za Slovenijo pridelava agrogoriv neprimerna strateška usmeritev. Višjo stopnjo samooskrbe predvsem z žiti (zlasti pšenico) pa bi bilo možno doseči tudi ob upoštevanju predpostavke, da bi se domača prireja in poraba mesa zmanjšala. Velja tudi podčrtati, da spodbujanje lokalne oskrbe s hrano in dopolnilne dejavnosti prinašajo številne pozitivne gospodarske, socialne, zdravstvene in okoljske učinke (Potočnik Slavič, 2010).

Za dosego najmanj 70-80 \%-ne prehranske samooskrbe Slovenije (rastlinska pridelava) bi morali do leta 2030 kmetijska zemljišča povečati za okoli tretjino, v najslabšem primeru pa vsaj za četrtino. V prehodnem, sonaravno zasnovanem kmetijskem prehodu in ob ponovni obdelavi opuščenih kmetijskih zemljišč namreč ne bi bilo primerno, da bi na netrajnostni način (bistveno) povečevali kmetijske donose na ha. Obenem pa velja podčrtati, da bodo v prihodnje celotno proizvodno-okoljsko vrednost vseh bioproduktivnih zemljišč določala tudi njihova zmogljivost ekosistemskih storitev, ki jih močno kemizirana kmetijska zemljišča ne morejo opravljati.

Kmetijska zemljišča $\mathrm{v}$ uporabi bi bilo treba $\mathrm{v}$ naslednjih dvajsetih letih povečati $\mathrm{s}$ sedanjih 470.000 ha na okoli 600.000 ha. Tako bi dosegli strateški prehranski minimum kmetijskih zemljišč v uporabi, ki znaša v naših geografskih razmerah okoli $3000\left(3500 \mathrm{~m}^{2}\right)$ na prebivalca. $Z$ vidika povečanja prehranske varnosti Slovenije na varno stopnjo (70-80 \%) pa je ključno zlasti povečanje njivskih površin (z vrtovi), kjer bi potrebovali vsaj 250.000 ha oziroma vsaj $1250 \mathrm{~m}^{2}$ na prebivalca namesto 170.000 ha (pod $900 \mathrm{~m}^{2}$ na prebivalca) $\mathrm{v}$ letu 2010. Po grobih ocenah naj bi sicer namesto $880 \mathrm{~m}^{2}$ njivskih površin na prebivalca $\mathrm{V}$ letu 2009 za kritje prehranskih potreb na podlagi lastne pridelave potrebovali okoli 2000 $\mathrm{m}^{2}$ (Perpar, Udovč, 2010). Površine žitaric (zlasti bistveno večje površine pšenice, ki so leta 2010 znašale že manj kot 32.000 ha) naj bi leta 2030 obsegale vsaj 140.000 ha, površina žitaric na prebivalca pa naj bi bila vsaj $700 \mathrm{~m}^{2}$ namesto sedanjih $500 \mathrm{~m}^{2}$. Ob približno enakem hektarskem donosu naj bi leta 2030 pridelali vsaj 600.000 ton pšenice in koruze za zrnje, kar bi ob vseh drugih potrebnih ukrepih in postopnem potrebnem spreminjanju prehranskih navad (manj mesa) v obdobju zgolj delno predvidljivih posledic podnebnih sprememb omogočilo varnejšo (ne pa popolnoma varno) prehransko prihodnost prebivalcev Slovenije (300 kg domačih žit na prebivalca). Prevlada trajnostno zasnovane kmetijske pridelave bi povečala število delovnih mest $\mathrm{v}$ kmetijstvu (in dopolnilnih dejavnostih), večji pomen pri prehranski samooskrbi pa bodo ponovno pridobile za slovenske razmere tradicionalne mešane kmetije in pridelava hrane $\mathrm{v}$ mestih.

V prvem obdobju sonaravnega kmetijskega prehoda (2012-2015) je osrednja naloga skrbno varovanje obstoječih kmetijskih zemljišč, saj gre za zagotavljanje ene od treh materialnih osnov biološkega preživetja in napredka države, regije, občine in posameznika (voda - hrana - zdravo okolje). Učinkovita zaščita najboljših kmetijskih zemljišč je torej v 
trenutku, ko imamo manj kot $900 \mathrm{~m}^{2}$ njivskih in manj kot $500 \mathrm{~m}^{2}$ žitnih površin na prebivalca (povprečje EU: nad $2000 \mathrm{~m}^{2}$ njivskih in $1000 \mathrm{~m}^{2}$ žitnih površin na prebivalca!), zgolj prvi nujni ukrep na državni ravni.

V drugem obdobju (2016-2030) pa bo Slovenija dobesedno eksistenčno prisiljena, da bistveno poveča kmetijske, zlasti pa njivske površine in se močno približa želeni, visoki stopnji prehranske samooskrbe kot pomembnem elementu preživetja in nacionalne varnosti. Prednostno in dolgoročno eksistenčno ključno varovanje kmetijskih zemljišč mora biti pred kratkoročnimi ekonomskimi interesi in pritiski kapitala.

Dejstvo je tudi, da je pridelovalni potencial ravninskih in bolj zaokroženih kmetijskih zemljišč zelo težko ekvivalentno nadomestiti (Odnos do kmetijske zemlje, 2010). Bistveno večji napor pa bo potreben za zelo pomembno sanacijo okoljsko degradiranih površin (npr. gramoznic, industrijskih, rudarskih in premogovnih površin), ki so praviloma v ravninskem svetu. Trajnostno načelo pomeni, da naj bi okoljsko sanirane površine v prihodnje ne bile $\mathrm{v}$ celoti pozidane, temveč v določenem obsegu namenjene tudi za pridelavo hrane in za ponovno opravljanje ekosistemskih storitev. Ohranjanje in ekosistemsko skrbno pretehtano ponovno (omejeno) povečanje kmetijskih površin v geografsko mozaični Sloveniji ne bi bilo v nasprotju z ohranjanjem narave, biotske pestrosti. Skoberne (2000, str. 258) ugotavlja, da so nekatere vrste v Sloveniji izumrle tudi zaradi opuščanja tradicionalnih oblik rabe zemljišč, kot je npr. opuščanje košnje ekstenzivnih kraških travnikov.

Povečanje prehranskega pomena hribovitih območij je skupaj s trajnostno zasnovo gozdarstva in podeželskega turizma ključnega pomena za udejanjanje skladnejšega, sonaravnega regionalnega razvoja Slovenije. Razmere na trgu kažejo, da je ponudba ekološko pridelane hrane v Sloveniji še vedno manjša od povpraševanja. Možnosti tovrstne pridelave torej še niso izkoriščene, saj ima Slovenija omejene naravne možnosti za visoko produktivno kmetijstvo (Perpar, Udovč, 2010; Lampič in sod., 2010). V letu 2009 je bilo zgolj 29.400 ha ekološko obdelanih površin (6 \% vseh kmetijskih površin), površine pa so se glede na leto 2008 celo nekoliko zmanjšale (Poročilo o razvoju, 2011).

\section{SKLEP}

Leta 2010 je okoli milijarda prebivalcev sveta trpela zaradi kronične lakote. Kmetje sveta so sicer pridelali dovolj hrane, vendar je hrana prostorsko neenakomerno razporejena in najbolj revnim zaradi naraščajočih cen vse bolj nedostopna. Prihaja do prvih znakov pomanjkanja hrane na svetovnem trgu. Globalne razmere kažejo, da bo v prihodnjih desetletjih hrana postala ključna geostrateška surovina in skupaj z vodo usmerjala našo prihodnost. Svet mora hkrati rešiti tri medsebojno povezane probleme v zvezi s hrano: izkoreniniti lakoto, povečati svetovno pridelavo hrane brez ogrožanja prihodnjih generacij in biosfere ter drastično zmanjšati kmetijske pritiske na okolje. Navedeni cilji so do leta 2050 dosegljivi z naslednjimi temeljnimi trajnostno zasnovanimi globalnimi ukrepi:

- zaustaviti širjenje kmetijskih površin na območja tropskega deževnega gozda;

- povečati donose na številnih kmetijah, kjer so donosi nizki, na trajnostno sonaravni način;

- povečati učinkovitost rabe vode in gnojil, ohranjati naravno rodovitnost prsti; 
- zmanjšati porabo mesa na prebivalca;

- zmanjšati izgube hrane in energije $\mathrm{v}$ pridelavi, prevozu in porabi ter povečati prehransko samooskrbo držav in regij.

Globalna prihodnost glede prehrane je negotova, geopolitično in socialno zelo eksplozivna, predlagane radikalnejše sonaravne ukrepe pa bo glede na izjemne profite in načrte obstoječih kmetijskih lobijev zelo težko uveljaviti. Zagotavljanje prehranske varnosti svetovnega prebivalstva $\mathrm{v} 21$. st. v okviru trajnih zmogljivosti ekosistemov bo v obdobju podnebnih sprememb vsekakor ena ključnih ter najzahtevnejših nalog človeštva in vseh odgovornih držav. Naraščajoči stroški, podnebne spremembe in negativne posledice ekosistemsko destruktivnega sistema pridelave hrane dobesedno silijo vladne politike in pridelovalce hrane k sonaravnemu in agroekološkemu modelu kmetovanja. Metode in tehnike proizvodnje trajnostnega kmetijstva povezujejo družbene, okoljske in tehnološke vire znotraj regij, kar ustvarja bolj raznovrstne agrarne sisteme pridelave hrane (Sage, 2012).

Prihodnja prehranska varnost svetovnega prebivalstva je odvisna od stabilizacije naslednjih ključnih kmetijskih virov:

- obdelovalnih zemljišč - zaščita pred erozijo, zastrupljanjem in pozidavo, agroekološka pridelava hrane;

- vodnih virov - učinkovitejše oblike namakanja, stabilizacija gladine talne vode;

- $\quad$ pašnih zemljišč - preprečitev prekomerne paše;

- $\quad$ svetovnega podnebja - čimprejšnja stabilizacija temperatur.

Za zagotavljanje prehranske varnosti Slovenije v obdobju stabilizacije njenega prebivalstva sta ključna naravna predpogoja zadosten obseg kakovostnih kmetijskih zemljišč in ohranjanje rodovitnosti prsti. Cilj pa je ne le ohranjanje najbolj rodovitnih kmetijskih zemljišč, temveč povečevanje kmetijskih površin, še posebej njivskih, zlasti žitnih površin (Poročilo o delovanju ..., 2012). Z vidika prehranske varnosti je nedopustno spodbujanje pridelovanja koruze za potrebe bioplinarn, raba odpadne gnojevke na vodnoekološko zelo občutljivih zemljiščih ter raba drugih poljščin za pridelavo biodizla na najboljših kmetijskih površinah. Večjo skrb in sredstva bo potrebno nameniti tudi povečanju sonaravne, učinkovite rabe vode za namakanje. Ohranjanje obstoječih in, zgodovinsko gledano, ekosistemsko in poselitveno zelo premišljeno ponovno povečanje kmetijskih zemljišč (zlasti zaraščenih površin) sta torej ključna pogoja za dosego varne stopnje samooskrbe Slovenije s hrano. Dejstvo je, da je Slovenija prešla iz razmerja 50 \% gozdov in 50 \% ostalih površin v petdesetih letih 20. st. na razmerje $60: 40 \%$ v korist gozdov.

Prehranska samooskrba Slovenije oziroma vsaj visoka stopnja samooskrbe (najmanj 70-80 \% namesto tvegane $50 \%$ ) do leta 2030 je v pričakovano zelo težavnih, negotovih svetovnih razmerah glede možnosti uvoza hrane ena od eksistenčnih podstati preživetja in napredka. Ker se bodo torej globalne potrebe po hrani v zaostrenih podnebnih razmerah nedvomno povečale, lahko razen še nadaljnjega povečanja cen hrane pričakujemo tudi vse večje geopolitične pritiske pri zagotavljanju uvoza pičlih viškov hrane. Ker Slovenija ni pomembna geopolitična sila, je toliko bolj strateško in eksistenčno pomembno, da pridela dovolj hrane za lastne potrebe. 


\section{Viri in literatura}

Andreae, B., 1983. Agrargeographie: Strukturzonen und Betriebsformen in der Weltlandwirtschaft. Berlin in New York, Walter de Gruyter, 504 str.

Brown, L. R., 2005. Outgrowing the Earth. The food security challenge in an age of falling water tables and rising temperatures. London, Earthscan, 239 str.

Brown, L. R., 2008. Plan B 3.0 - mobilizing to save civilisation. New York, W. W. Norton, 398 str.

Diamond, J., 2006. Collapse - how societies choose to fail or succeed. London, Penguin Books, 575 str.

Hrustel Majcen, M., 2004. Trajnostni razvoj in kmetijstvo. V: Lah, A. (ur.). Sonaravno uravnoteženi razvoj Slovenije. Ljubljana, Svet za varstvo okolja RS, str. 99-102.

Key figures on Europe. 2010. Luxembourg, Publications Office of the European Union, 245 str.

Klemenčič, M. M., 2010. Podeželska idila ali koma slovenskega tradicionalnega podeželja. V: Zavodnik Lamovšek, A., Fikfak, A., Barbič, A. (ur.). Podeželje na preizkušnji: jubilejna monografija ob upokojitvi izrednega profesorja dr. Antona Prosena. Ljubljana, Fakulteta za gradbeništvo in geodezijo, str. 24-29.

Korošec, V., Pak, M., 2010. Razvojna problematika Haloz na primerih katastrskih občin Gorca in Slatina. Dela, 34, str. 91-114.

Lampič, B., Mrak, I., Potočnik Slavič, I., Bednář, P., Žufan, P., 2010. Characteristics of organic food consumers in urban regions of Ljubljana and Ostrava. Dela, 34, str. 2338.

Lincoln, S. F., 2006. Challenged Earth. An overview of humanity's stewardship of Earth. London, Imperial College Press, 533 str.

Maxey, L., 2007. From 'alternative' to 'sustainable' food. V: Maye, D., Holloway, L., Kneafsey, M. (ur.). Alternative food geographies - representation and practice. New York, Elsevier Science, str. 55-76.

Mays, L., 2007. Water resources sustainability. New York, McGraw-Hill, 330 str.

Nierenberg, D., Halweil, B., 2005. Cultivating food security. V: State of the World 2005. New York, Worldwatch Institute, str. 62-77.

Ocena stanja v kmetijstvu v letu 2010 (jesensko poročilo). 2011. Ljubljana, Kmetijski inštitut Slovenije, 35 str. URL: http://www.arhiv.mkgp.gov.si/si/splosno/vstopna_stran/aktualne teme/porocilo_o_stanju_kmetijstva_zivilstva_in_gozdarstva/ (Citirano 11. 6. 2012).

Odnos do kmetijske zemlje. Gradivo za razpravo pri predsedniku države. 2010. Ljubljana, Kabinet ministra za kmetijstvo, gozdarstvo in prehrano, 18 str.

Perpar, A., Udovč, A., 2010. Realni potenciali za lokalno oskrbo s hrano v Sloveniji. Dela, 34, str. 187-199.

Pierce, J., 1990. The food resource. New York, Longman Scientific \& Tehnical, 334 str.

Poročilo o delovanju Sveta za varstvo okolja Republike Slovenije od novembra 2010 do decembra 2011 (delovno gradivo izdelal F. Lobnik). 2012. Ljubljana, Svet za varstvo okolja RS. 
Poročilo o razvoju 2011. Ljubljana, Urad za makroekonomske analize in razvoj, 217 str. URL: http://www.umar.gov.si/fileadmin/user_upload/publikacije/pr/2011/POR_2011sn. pdf (Citirano 11. 6. 2012).

Poročilo o stanju kmetijstva, živilstva in gozdarstva v letu 2009. 2010. Ljubljana, Ministrstvo za kmetijstvo, gozdarstvo in prehrano ter Kmetijski inštitut Slovenije. URL: http://www. kis.si/pls/kis/!kis.web?m=36\&j=SI (Citirano 10. 6. 2012).

Potočnik Slavič, I., 2010. Vključevanje kmetov v oskrbne verige: primer dopolnilnih dejavnosti na slovenskih kmetijah. Dela, 34, str. 5-22.

Raman, S., 2006. Agricultural sustainability - principles, processes and prospects. New York, Food Products Press, 474 str.

Resnik Planinc, T., Ilc, M., 2010. Izobraževanje za lokalno trajnostno oskrbo s hrano. Dela, 34, str. 167-186.

Sage, C., 2012. Environment and food. London, Routledge, 320 str.

Skoberne, P., 2000. Biotska raznovrstnost v Sloveniji. V: Flajšman, B. (ur.). Naprej k naravi. II. zbornik referatov strokovnega posveta Ekološkega foruma Liberalne demokracije Slovenije in dokumenti foruma. Ljubljana, Ekološki forum LDS, str. 253-265.

Statistični letopis Republike Slovenije 1992. 1992. Ljubljana, Statistični urad Republike Slovenije. URL: http://www.stat.si/letopis/index_vsebina.asp?leto=1992\&jezik=si (Citirano 28. 10. 2012).

Statistični letopis Republike Slovenije 2010. 2010. Ljubljana, Statistični urad Republike Slovenije. URL: http://www.stat.si/letopis/LetopisPrvaStran.aspx?leto=2010\&jezik=si (Citirano 28. 10. 2012).

Statistični letopis Republike Slovenije 2011. 2011. Ljubljana, Statistični urad Republike Slovenije. URL: http://www.stat.si/letopis/letopisprvastran.aspx (Citirano 28. 10. 2012). Stutz, F., Warf, B., 2005. World economy. Resources, location, trade, and development. Upper Saddle River, N. J., Pearson/Prentice Hall, 543 str.

Suhadolc, M., Sušnik, A., Lobnik, F., Kajfež-Bogataj, L., Gregorič, G., Bergant, K., 2010. Izzivi Slovenije na področju suš in degradacije tal. Uresničevanje ciljev Konvencije ZN o boju proti degradaciji/dezertifikaciji tal (UNCCD). Ljubljana, Agencija RS za okolje, 75 str.

The European environment - state and outlook 2010. 2011. Luxembourg, European

Environment Agency. URL: http://www.eea.europa.eu/soer (Citirano 11. 6. 2012).

Woods, M., 2005. Rural geography. London, SAGE Publications, 330 str.

\section{FOOD SECURITY INTHE WORLD AND IN SLOVENIA}

\section{Summary}

The concept of food security includes the ability to provide food also in exceptional and critical circumstances, a safe level of potential self-sufficiency, and traceability of safely produced agricultural food. At the beginning of the 21 st century, it has become even more difficult to ensure food security for the increasing world population due to the negative effects of climate changes. 
After the year 2007, the situation on the global food market has been further aggravated, because planetary food security has been destabilized. Therefore, between 2008 and 2011, world prices of wheat, corn, sugar and oil rose extremely high, which had negative impacts especially on the welfare of poor inhabitants of the world who spend most of their meagre income on food. The consequences of more frequent summer droughts and floods in numerous countries have severely endangered food security of the planet and have caused an ever more alarming and geopolitically hazardous climate-food image of the warm planet. The high energy consumption and the output of greenhouse-gas transport-emissions during the long-distance food transportation are the crucial broader negative environmental impacts. A meal made of imported food (meat, cereals, fruits and vegetables) generates 4-times higher greenhouse-gas emissions than an equivalent meal prepared from local agricultural products.

According to numerous experts, to secure a continuing supply of healthy food (the expected increase in needs for food by about $100 \%$ by the year 2050) for all the inhabitants is the greatest and most probably also the most demanding global challenge of the 21st century, due to the climate change, realistic possibilities of numerous conflicts and greater social instability. The increase in world population by about 2 billion by the year 2050 and changes in the diet composition (from cereals to meat), alongside the improving material welfare, will heavily increase the demand for agricultural products (The European environment, 2011). According to the FAO data, the current food production will have to be increased by $70 \%$ by the year 2050 . The annual production should increase from 2.1 billion tons to 3 billion tons and the yearly meat production is expected to increase from 200 million tons to 470 million tons (Odnos do kmetijske zemlje, 2010). Because of the necessity to reduce world famine and the anticipated increase in needs for food in numerous developing countries by the mid-21st century, the following options are available in the future decades on the planetary level:

- increase in agricultural areas;

- increase in yields on the existing agricultural areas and the use of new food resources;

- essential decrease in the so-called discarded food in rich countries (up to one third of prepared food ends as trash) and a more even distribution of food in the world;

- changes in nutrition habits by maintaining the share of meat from livestock farms (the use of cereals) in the nutrition of inhabitants in developing countries and a continuous decrease in meat consumption in the countries of material welfare.

The future food security of the world population depends on the stabilization of the following crucial agricultural resources:

- arable lands - protection against soil erosion, contamination and building-up; agro-ecological food production;

- water resources - more efficient forms of irrigation, stabilization of water table;

- pasture lands - prevention from excessive pasturing;

- world climate - the soonest possible stabilization of temperatures. 
Because of the increasing global food- and environmental uncertainty and doubts about the long-term environmental sustainability of the present way of solving the problem of world famine, production and distribution of food, there are ever more experts who point out the ever greater importance of food self-sufficiency of countries, regions, local communities, and on agricultural practices which are adjusted to local environmental capacities. Also because of their own safety and long-term developmental interests, the rich countries should financially support the developing countries, so that the latter could feed their inhabitants on their own.

In the expected very difficult and uncertain world circumstances as to the possibility of food import, food self-sufficiency of Slovenia, or at least a high degree of its food selfsufficiency, is one of its existential bases for survival and safety. Because its agricultural areas have been largely overgrown and built-up, the extent of Slovenia's agricultural tillable land (fields and gardens) ranks it among the last EU countries, i.e. as the 24th of the 27 members. Cereal areas per inhabitant of Slovenia amounted to $500 \mathrm{~m}^{2}$ in 2007, while the world average was about $1000 \mathrm{~m}^{2}$.

The decline in field areas is the most evident cause of the strategically critical level of food self-sufficiency of Slovenia (50\%), but culpable is also poor exploitation of the natural agricultural potential. Expert assessments show that sufficiently big potentials of agricultural lands and water resources are available in Slovenia so that the present safety-hazardous, very low level of general food self-sufficiency $(50 \%)$ could be increased to a safe level $(70-80 \%)$. To maintain the existing agricultural lands and to increase them by resuming the old ones (particularly the overgrown areas), from the historical point of view very well premeditated as to ecosystem-related issues, are the crucial conditions for attaining a safe level of food self-sufficiency in Slovenia. Forest now covers about $60 \%$ of the territory of Slovenia; if about a half of Slovenia remained covered with forest, while the overgrown areas were transformed into agricultural lands, the situation would be sufficiently balanced as to the ecosystem, food, wood and settlement.

(Translated by Branka Klemenc) 